\title{
Resisting the Defeatism of Epidemic: A Critical Study of the Plague by Albert Camus
}

Arti

Student (MA. English)

School of Humanities

Department of English

Lovely Professional University

Phagwara, Punjab India

Dr. Muzafar Ahmad Bhat

Assistant Professor

School of Humanities

Department of English

Lovely Professional University

Phagwara, Punjab India

muzafar.25623@lpu.co.in

\begin{abstract}
Most plague texts have their genesis in fact. The Plague is no exception. Therefore, to study the aesthetics of plague literature-or more particularly, the aesthetic constructs of destiny in plague literature - is to examine the process by which the factual reality of plague is first perceived and then translated by an author into a literary reality. A process that begins in perception - and indeed, the ancient Greeks defined aesthetics as perception - thus ends in representation; the plague text re-presents plague's fact.
\end{abstract}


Keywords: Plague, disease, fatalist, science, religion, belief, history, sin, defeat

Introduction

Set in the coastal city of Oran in Algeria in the unspecified year of 194-, the genesis of Camus's The Plague, published in post-war 1947, in all likelihood lies in the outbreak of bubonic plague in Oran in the 1940s. In the composition of the novel, however, Camus, whose Notebooks attest to his wide reading in plague literature, is likely to have drawn on the accounts of various epidemics that darkened the history of Algeria, a principal one being the cholera epidemic that killed a large percentage of Oran's population in 1849, following the French colonization. Oran and its environs had in fact suffered numerous epidemics in the four centuries before Camus published his novel. A research report by the Center for Disease Control and Prevention shows that Oran was decimated by bubonic plague in 1556 and in 1678 (with deaths estimated at 3,000), whereas outbreaks of plague after European colonization-185 cases in 1921, 76 in 1931, 95 in 1944 - fell far short of the epidemic described in the novel. Oran's last case of plague in a human, prior to publication of Camus's novel, was recorded in 1946.

Although Camus locates the novel in the French colony of Algeria in North Africa, the city of Oran feels essentially European, and all of Camus's central characters are of European descent. The geography fixes a distance between the colony and France, between North Africa and Europe, at the same time that the unexceptional cultural disposition of the populace obliterates it. Oran and its citizenry are, in fact, so very ordinary, so unremarkably like people anywhere else, so extraordinary-resistant, that in the opening paragraphs, in David Richter's reading of the novel as a modern apologue in Fable's End, "[t]he stage is ... set for a fable in which the effects of the bubonic plague upon the town may become 
emblematic of man's confrontation with the absurdity of the universe" (17). Oran is thus less significant as the city in which a plague appears than as any city in which plague may unexpectedly, absurdly, appear. And in Oran it does what in any city it might: It arrives, no one knows from where. Its cause is impossible to ascertain; its etiology remaining unclear, its course is impossible to predict or explain. Indiscriminately it kills by the hundreds, for days, weeks, months. Death tolls rise until the bacillus begins to attenuate. Until the pestilence itself seems to die. For, mysteriously, it goes away.

Camus's The Plague, offers a realistically detailed chronicle of the plague in Oran; but concealed, and revealed, in that chronicle is a tale that invests the plague with a larger, more universal, mythic significance. Thus the novel can be read both literally, in concrete terms of a specific plague, and symbolically, in abstract terms of a mythic plague; and in between, the novel no doubt offers possibilities that can be read metaphorically, in the figurative terms of a political or social plague.

Camus's The Plague founds its argument in the dichotomy between science and religion - or as Camus put it in his Notebooks, "the struggle between medicine and religion; the powers of the relative ... against those of the absolute"-(4) out of which arise numerou s corollaries of duality, like reason and faith, empiricism and metaphysics, epidemiology and dogma, humanism and Christianity. More modern, and more relevant in its empirical approach to the problem at hand, though Rieux's scientific perspective may be than Paneloux'smetaphysical one, both constructs will in the end prove to be contrarily aesthetic. Out of their contrariety and their conjunction-out of the intellectual conflict between the earthly, humanist practitioner of medicine and the tortured medievalist priest who would save mankind's soul-emerges the novel's aesthetic construct of destiny. Philosophically and psychologically, the linear-thinking metaphysician is pitted against the mythopoeic sensibility of an empiricist who has perceived in history the cyclical nature of plague and observed 
firsthand, as an epidemiologist, its effects in the world it inhabits - and who, in the end, in his role as narrator, asserts what he can now fully imagine: As inevitable as its destiny is the certainty of the plague's eternal return.

Ultimately in Camus's multi-layered narrative the plague defines and is defined by virtually every narrative detail, every novelistic turn of event, every intellectual posture, every disposition of character, every ambiguity, and every metaphor. Yet, at the same time, plague defies the constructs that would contain or explain it; its full reality lies always beyond the intelligence and imagination of its interpreters. Camus acknowledges (as does his narrator) the inadequacy of the human intellect, be its perspective scientific or metaphysical, in its attempts to make comprehensible a thing that is in itself incomprehensible or, equally frightening, a thing that in itself simply is. For Camus (and the narrator), plague assumes its own destiny. It is. And when it isn't it will be again.

In The Plague Camus's Dr.Rieux serves a dual purpose. A man of science and a doctor dedicated to tending the sick and the dying, he is the protagonist of the plague narrative. He is also the narrator of the tale, however, as he discloses at the end of the novel when he prepares to turn the entries in his journal (as well as those in the diaries of his friend, the plague victim Tarrou) into a chronicle of the plague in Oran, which, of course, is essentially the eyewitness account the reader has just read. In this, Camus acknowledges his debt to Defoe, who used a similar device in Journal of a Plague Year, by which H. F. presents the events in London as if they were unfolding before him at the very time he is recording them, thus to heighten with immediacy the illusion of reality. Like Defoe's self-effacing H. F., too, Camus's narratorialRieux incorporates scientific detail, like statistics in regard to dayto-day fatalities, to lend further authenticity to the horror that has been visited upon the citizens of Oran. 
Empirical observation and modern epidemiology afford Rieux a construct by which to present the threat of the plague and to forecast the destiny of - and his hope for - the community. However, his empirical evidence proves to be suspect and his knowledge of epidemiology unconvincing to the town elders. Oran's prefect is likewise reluctant to come to terms with the possible reality of an epidemic when Rieux and his colleagues press him to convene a "health committee [commission sanitaire]" (45), although the health committee itself will be reluctant to call for drastic measures in a situation that is not yet apparently drastic. Rieux the empiricist would hardly cast himself as a prophet, but he would exercise, and recommend, foresight on the basis of scientific evidence: "The point isn't whether the measures provided for in the code are rigorous, but whether they are needful to prevent the death of half the population" (47).

Not a prophet, an empiricist for sure, a chronicler and a doctor, a student of history and a man of science, Rieux brings his knowledge of the historical past to bear upon his observations of the current outbreak of disease in Oran. To that knowledge, historical and scientific, he adds imagination. Rieux imagines fully what might be-and soon proves to be-the consequence of the ignorance and denial that insulate the prefect, the health committee, and the community at large from a timely confrontation with destiny, a destiny that Rieux deems to be inevitable. The empiricist is also a fatalist; but his is a fatalism that demands not surrender to an abstract principle but action in spite of it. Rieux's foresight benefits from hindsight, as his perception of the present is prefaced by his familiarity with the past and his empiricism is wedded to his imagination. Rieux embraces all the contraries that spur him into action. All serve to define, and determine, Rieux's conception and construction of himself as, primarily, a medical practitioner actively committed to Oran's battle against a bacillus, and in that commitment he perceives and pursues his personal destiny in the face of plague. The fatalist in Rieux does not submit to fate; rather, he combats it. 
The same might be said of its history, and destiny. As Rieux presents it, the destiny of plague is played out in history. So it is that plague, for Rieux, can only be comprehended in terms of the past, which, as yet, to his scientific mind, has yielded no cause for the pestilence as history has recorded it. Destiny is thus defined historically by the plague's effects, more of which are yet to be evidenced, as they will continue to evolve in the future that history has yet to write. Beyond history, then, destiny is a blank, for like history it is always in the process of being written, which does not prevent it from being divined, however falsely, inaccurately, or prejudicially. But Rieux is not a diviner, prophet, or seer. He is a scientist; he allows the facts of the present case to speak for themselves and the facts as he presents them are descriptive, not predictive or even prescriptive, for the facts even now, in light of a protean bacillus, fail to reveal a fixed cause. (Besides, the bacillus explains only the scientific how, not the more speculative why.) Ignorance of cause of course does not equal absence of cause. Nor do Rieux's facts preclude fiction; for his history of plague's evident effects as well as his chronicle of them in Oran is shaped by his perception of plague's apparent destiny, and as such his scientific discourse, which strives for bald objectivity, is an aesthetic construct colored inevitably by his imagination and subjectivity: none of which casts into doubt his integrity as a scientist and humanist.

\section{Conclusion}

Furthermore, for Camus's rebel, as Herbert Read observes, "revolt is one of the 'essential dimensions' of mankind."(10) Neither the Hegelian revolt of the slave against the master nor the Marxist revolt of the proletarian against the ruling class, Camus's is a metaphysical revolt against the conditions of life defined by the idea of divine justice. Rieux's rejection of the divine, though, does not equal a Luciferian non serviam, for while the atheist Dr.Rieux will not serve God, he will serve humanity—-he will participate fully in "the 
destiny of all men." He is in fact compelled to serve his fellow human beings. Because God won't. In a God-absent universe humankind perforce has to take responsibility for its destiny. Like Camus's truly absurd yet absurdly happy Sisyphus, Rieux refuses to give in to the never-ending possibility of defeat. As Rieux notes, "Everyone knows that pestilence has a way of recurring in the world" (35) 


\section{References}

Camus, Albert. The Plague, The Fall, Exile and The Kingdom, and Selected Essays. Trans. Stuart Gilbert. New York: Alfred A. Knopf, Everyman’s Library,Print. 2004.

-----------. The Rebel. Trans. Anthony Bower. New York: Vintage Books,Print. 1956.

Cruickshank, John. Albert Camus and the Literature of Revolt. London: Oxford University Press, Print.1959.

Hegel, Friedrich. Introduction to the Philosophy of History. Trans. Leo Rauch. Cambridge: Hackett Publishing Company, Print.1988.

Read, Herbert. "Introduction.” Albert Camus. The Rebel. Trans. Anthony Bower. New York: Vintage Books, Print.1956.

Thucydides. "The Plague of Athens." The Peloponnesian War, Chapter 47. Trans. C. F. Smith. Cambridge: Cambridge University Press, Loeb Classical Library, Print.2001. 